\title{
Landslides in Padang, West Sumatra, triggered by the September 2009 offshore earthquake
}

\author{
Toshiyasu UENO $^{1}$ and Shusaku SHIIBA ${ }^{1}$ \\ 1 JICA Expert, Directrate General of Water Resources, Ministry of Public Works, Indonesia \\ (Sentral Senayan II ,Lt.14, Jl. Asia Africa No.8, Gelora Bung Karno, Senayan, Jakarta 10270, Indonesia)
}

\begin{abstract}
On 30 September 2009, numerous landslides occurred in a mountain-ringed region of West Sumatra, Indonesia, triggered by an earthquake off the coast of Padang. The landslides blocked roads in the region, hindering efforts to determine the extent of the damage. Analyses of satellite images (coverage area 1,500 $\mathrm{km}^{2}$ ) of the most severely damaged districts, Padang Pariaman and Agam, revealed that 253 landslides had occurred. Severe landslides, involving more than 1 million $\mathrm{m}^{3}$ of collapsed sediment, were observed at 10 sites within the study area.
\end{abstract}

Key words: landslide, mudflow, earthquake, satellite image, Padang

\section{INTRODUCTION}

On 30 September 2009, a magnitude 7.6 earthquake occurred in the Indian Ocean off the coast of Padang in the province of West Sumatra, Indonesia, at 5:16 p.m. (Western Indonesia Time). According to the US Geological Survey, the earthquake's center was located at $0.725^{\circ} \mathrm{S}$, $99.856^{\circ} \mathrm{E}$ with a hypocenter depth of $81 \mathrm{~km}$ (Fig. 1). The earthquake caused 907 deaths and another 210 people are still missing.

Enormous damage occurred in areas close to the earthquake's origin, especially in the cities of Padang and Pariaman and the nearby district, where many residences and other buildings collapsed. Numerous slope collapses also occurred in nearby mountainous regions. It took time to assess the extent of the damage because roads were blocked by landslides, and water and electricity services were severed in many places.

We conducted field investigations between 3 and 5 October 2009. Here, we report our field findings as well as the results of our analysis of satellite images of approximately $1,500 \mathrm{~km}^{2}$ of the most damaged areas.

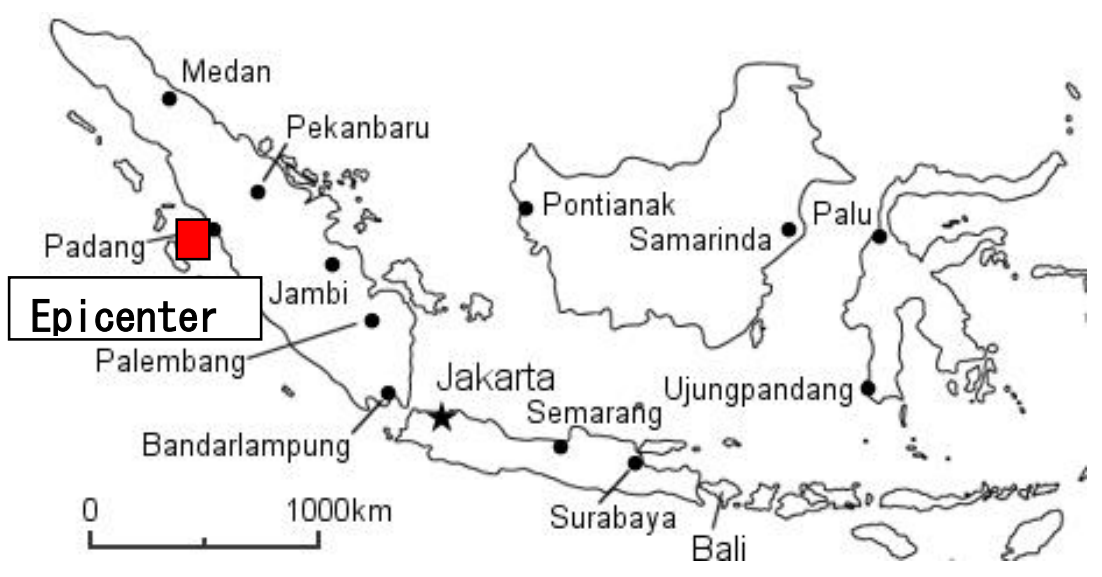

Fig. 1 Epicenter of the earthquake off the coast of Padang, West Sumatra, Indonesia 


\section{FIELD INVESTIGATION}

We investigated the earthquake damage in the city of Padang on 3 October and conducted field investigations in the surrounding Padang Pariaman district on 4 and 5 October 2009. Many landslides and collapses occurred in this.

\subsection{Conditions in Padang}

Most areas in the city of Padang were still accessible by car. Some residences and other buildings had collapsed and the electricity was off. We observed some cracks and breakage in slope and bank protection structures, but while some new flank collapses had occurred on hillside slopes near Padang, none of these were massive landslides.

\subsection{Conditions in Padang Pariaman}

\subsubsection{Overview}

Many landslides and collapses had occurred in the mountain-ringed district of Padang Pariaman, located north of the cities of Padang and Pariaman. Roads through the district were blocked by landslides, delaying efforts to assess the extent of the damage. In this mountain-ringed region, more than $50 \%$ of buildings (including private homes) had collapsed; this is much higher than the collapse rates in the cities of Padang and Pariaman.

\subsubsection{Landslide disasters}

As part of our field investigation, we visited a landslide site in the upper area of the Naras river $\left(0.485^{\circ} \mathrm{S}, 100.227^{\circ} \mathrm{E}\right)$ (Figs. 2, 3). Three landslides occurred in this area, becoming mudflows that joined and flowed downstream (Figs. 4, 5, 6). Large volumes of unstable sediment from these landslides also accumulated on slopes and along the mountain stream.

According to a geologic map of Padang [Kastowo et al., 1996], this area consists of volcanic rocks, mostly pumice and volcanic lapill, with diameters of $2-10 \mathrm{~cm}$. The site is deeply weathered.

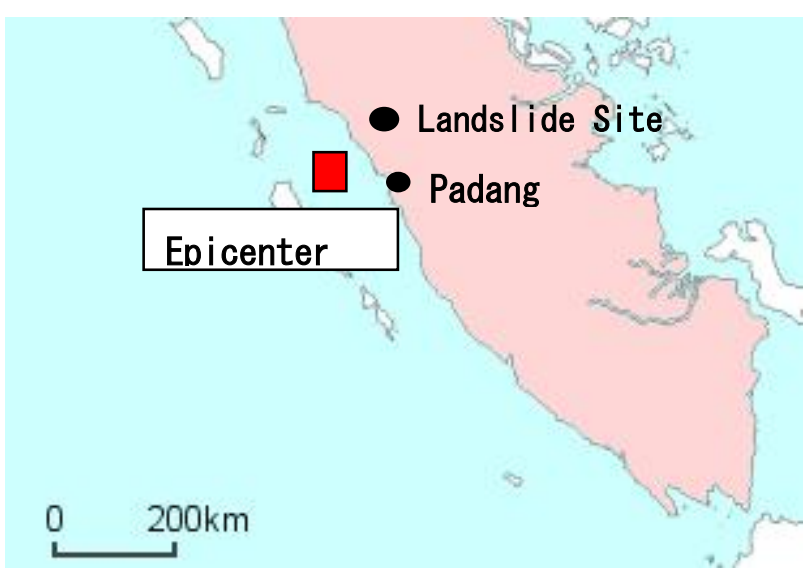

Fig. 2 Landslide occurrence sites

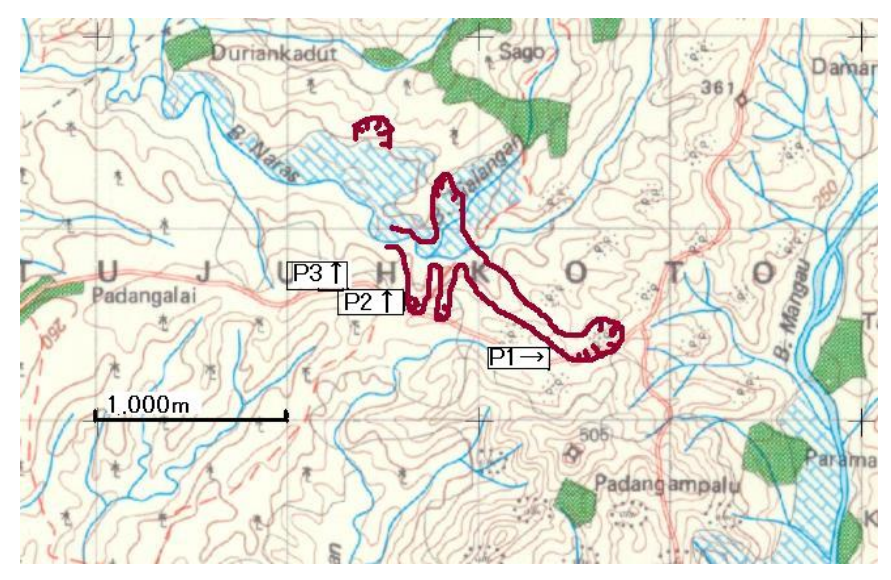

Fig. 3 Landslide occurrence sites and photograph points

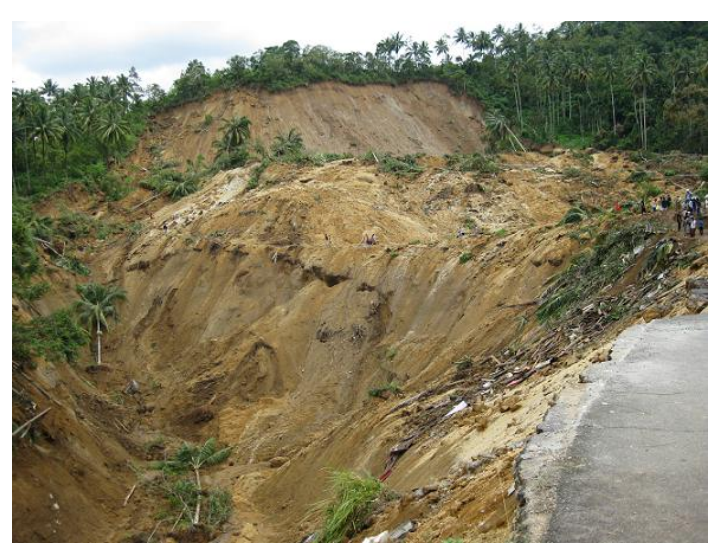

Fig.4 A landslide disaster (P1) 


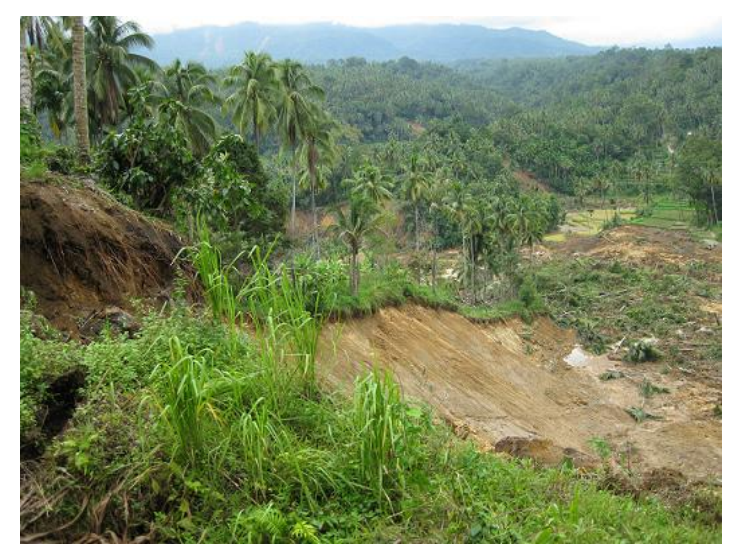

Fig.5 A mudflow landslide (P2)

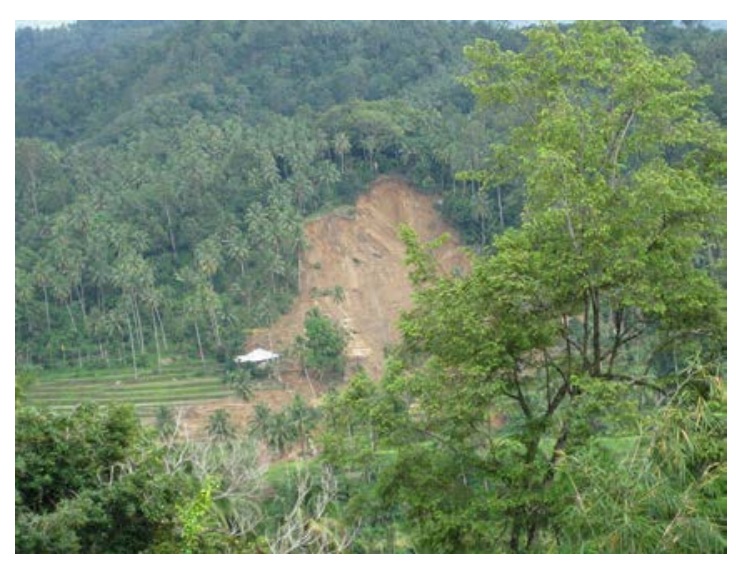

Fig.6 Landslide points on a hillside (P3)

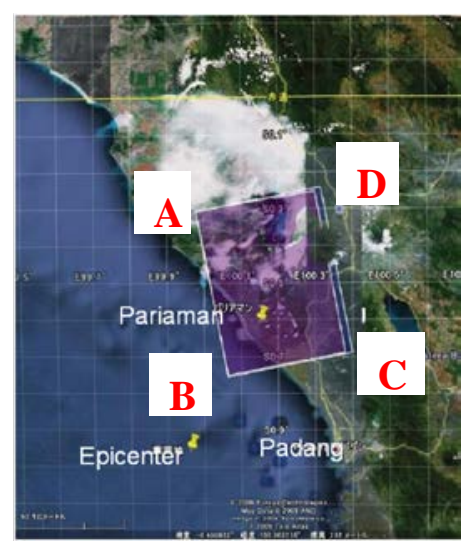

Fig.7 Region covered by the analyzed satellite imagery

\section{SATELLITE IMAGE ANALYSIS}

Because landslides occurred over a wide area and many roads in the region were blocked, it was difficult to determine the comprehensive damage at the time of our field investigations. To estimate the landslide sites and disaster conditions across the region, we used satellite images of the most severely damaged districts, Padang Pariaman and Agam.

\subsection{Satellite images}

We used images obtained by the German satellite TerraSAR-X. The X-band synthetic aperture radar (SAR) observations collected by this satellite are not influenced by clouds and have a spatial resolution of 3.3 to $3.5 \mathrm{~m}$. We compiled imagery within the following four Universal Transverse Mercator coordinate points: A -0.273 , 99.987; B $-0.761,100.080$; C $-0.701,100.379$; and D -0.214 , 100.284. The rectangle bounded by these points measured about $1,500 \mathrm{~km}^{2}(30 \mathrm{~km} \times 50 \mathrm{~km})$. We compared two satellite images: a pre-earthquake image taken on 28 February 2009 and a post-earthquake image taken on 8 October 2009 (Fig. 7).

\subsection{Method of interpretation}

We overlaid the two satellite photographs and determined the points that had changed as a result of landslides. We then estimated the volume of collapsed sediment at landslide sites using the following procedure:

1) Measure the width of the slope collapse identified in the satellite photograph

2) Multiply the width by 1.5 to estimate the length of the slope collapse

3) Multiply the width by 0.1 to estimate the depth of the slope collapse

4) Width $x$ length $x$ depth $x 0.5=$ the estimated amount of collapsed sediment

\subsection{Analysis results}

Using the satellite images, we identified 253 landslides (Table 1), amounting to an estimated total of $70,000,000 \mathrm{~m}^{3}$ of collapsed sediment. Of these landslides, 10 were classified as severe, each with more than 1 million $\mathrm{m}^{3}$ of collapsed sediment (Fig. 8). The collective volume of these 10 severe landslides, about $40,000,000 \mathrm{~m}^{3}$, represents about $60 \%$ of the total collapsed sediment volume in the study area (Table 2). These calculations excluded some mudflow areas; consideration of mudflow would make the estimates even higher. 
Table 1 Landslide sites and number and scale of landslides

\begin{tabular}{|c|c|c|c|}
\hline District & Subdistrict & Landslide & $\begin{array}{l}\text { Large } \\
\text { Scale* }^{\text {Scal }}\end{array}$ \\
\hline \multirow{14}{*}{$\begin{array}{l}\text { Padang } \\
\text { Pariaman }\end{array}$} & Lubuk Alung & 12 & 1 \\
\hline & Sintuk Toboh Gadang & 5 & \\
\hline & Nan Sabaris & 2 & \\
\hline & Enam Lingkung & 9 & 1 \\
\hline & Tujuh Koto Sungai Sarik & 1 & \\
\hline & $\begin{array}{l}\text { Dua Sepuluh Sebelas Enam } \\
\text { Lingkung }\end{array}$ & 9 & \\
\hline & Patamuan & 1 & \\
\hline & Sungai Limau & 8 & \\
\hline & Lima Koto Timur & 51 & 6 \\
\hline & Lima Koto Kampung Dalam & 27 & 2 \\
\hline & Batang Gasan & 1 & \\
\hline & Sungai Geringging & 10 & \\
\hline & Empat Koto Aur Malintang & 5 & \\
\hline & Sub Total & 141 & 10 \\
\hline \multirow{6}{*}{ Agam } & Empat Koto & 37 & \\
\hline & Tanjung Raya & 34 & \\
\hline & Lubuk Basung & 39 & \\
\hline & Empat Nagari & 2 & \\
\hline & Sub Total & 112 & 0 \\
\hline & Total & 253 & 10 \\
\hline
\end{tabular}

Large Scale: estimated volume $>1,000,000 \mathrm{~m}^{3}$ 


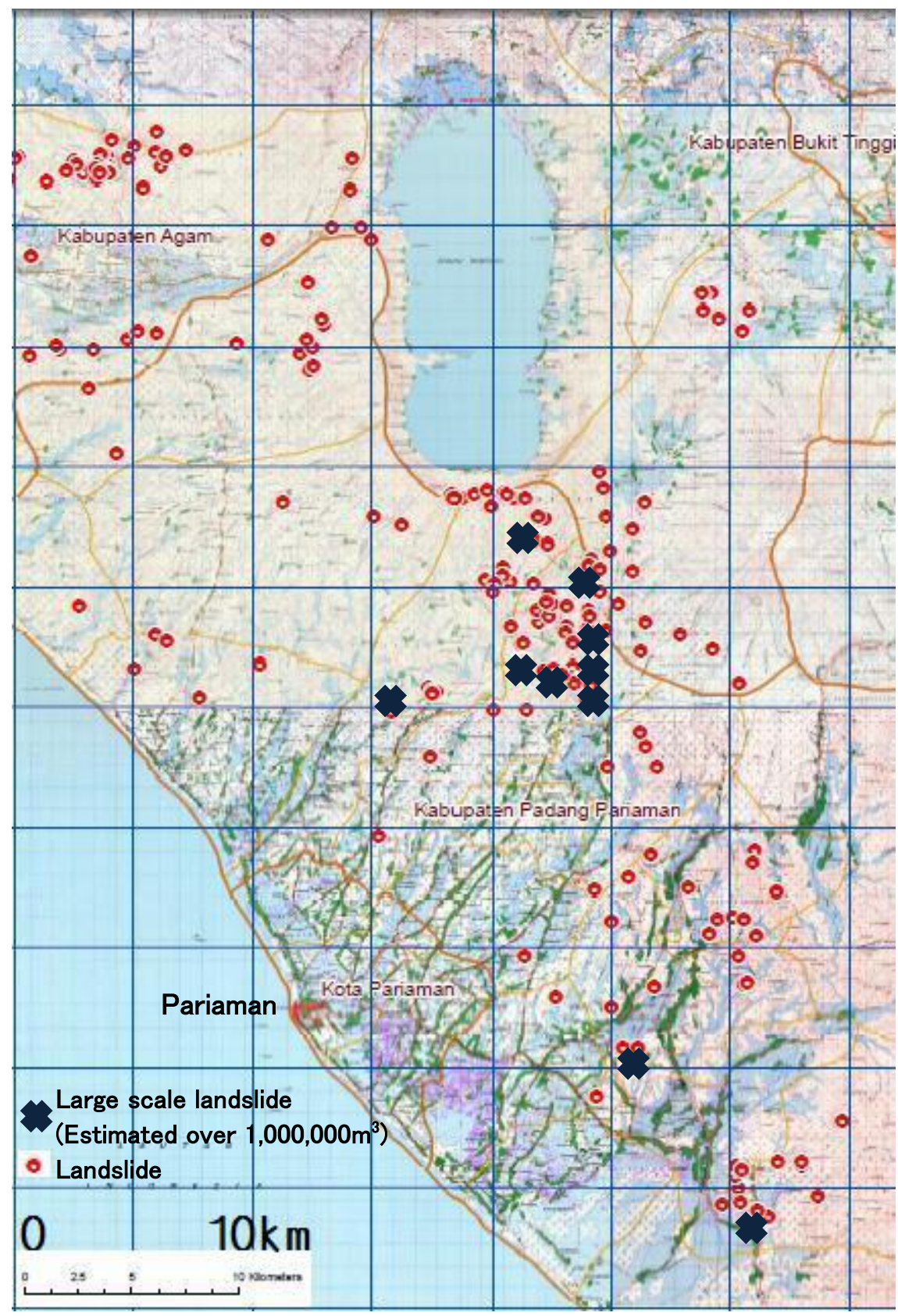

Fig.8 Distribution of landslides 
Table 2 Large-scale landslide sites (sediment volume $>1,000,000 \mathrm{~m}^{3}$ )

\begin{tabular}{|c|c|c|c|c|c|c|}
\hline No, & Subdistrict & Width ( & (m) & Length (m) & Depth (m) & Volume $\left(\mathrm{m}^{3}\right)$ \\
\hline 1 & Lubuk Alung & & 331 & 497 & 33 & $2,719,852$ \\
\hline 2 & Enam Lingkung & & 378 & 567 & 38 & $4,050,761$ \\
\hline 3 & \multirow{6}{*}{ Lima Koto Timur } & & 284 & 426 & 28 & $1,717,973$ \\
\hline 4 & & & 345 & 518 & 35 & $3,079,772$ \\
\hline 5 & & & 534 & 801 & 53 & $11,420,498$ \\
\hline 6 & & & 340 & 510 & 34 & $2,947,800$ \\
\hline 7 & & & 457 & 686 & 46 & $7,158,299$ \\
\hline 8 & & & 270 & 405 & 27 & $1,476,225$ \\
\hline 9 & \multirow{2}{*}{ Lma Koto Kampung Dalam } & & 296 & 444 & 30 & $1,945,075$ \\
\hline 10 & & & 245 & 368 & 25 & $1,102,959$ \\
\hline & & & & & Total & $37,619,215$ \\
\hline
\end{tabular}

\subsection{Relationship between topography and geology}

To refine the distribution of slope collapses, we analyzed the relationship between topography and geology at landslide sites. Most landslides occurred at sites with the following topographic or geologic features (Fig. 9) [Kastowo et al., 1996]:

1) Lineament, caldera, or caldera rim

2) Andesite of Lake Maninjau caldera

3) Hornblende hypersthene pumiceous tuff

4) Elevation similar to the lake surface of Lake Maninjau ( $\sim 500 \mathrm{~m}$ above sea level)

From these features, we inferred that many landslides occurred as a result of seismic movement and water supplied from Lake Maninjau, combined with a geographic predisposition to landslides.

Many slope collapses were concentrated in the Naras and Mangau river basins, which were near the earthquake's center (Fig. 10). A caldera rim surrounds Lake Maninjau, and the steepness of the caldera slopes contributed to landslides in this area [Frattini et al., 2004; Hürlimann et al., 2001; Zanchetta et al., 2004].

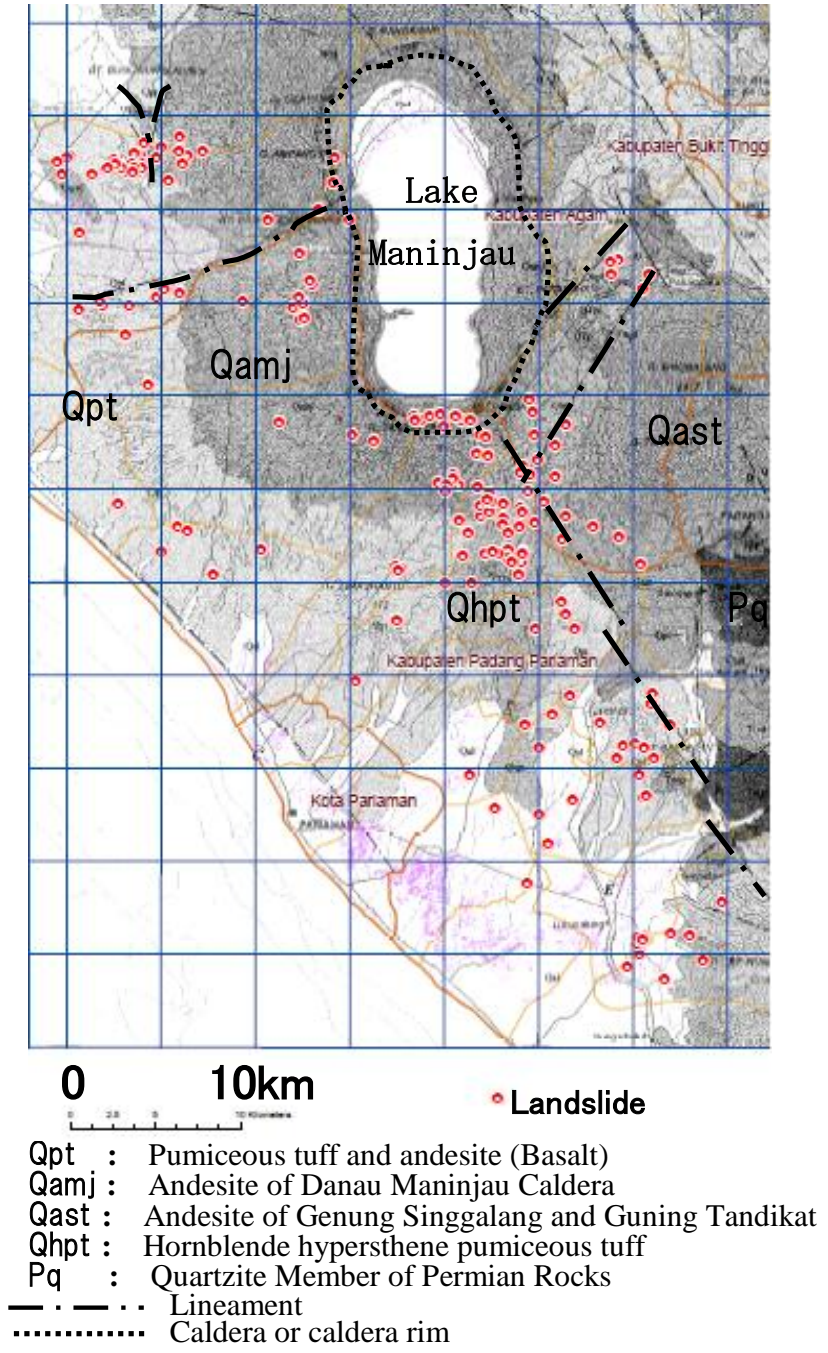

Fig.9 Landslide distribution and geology 


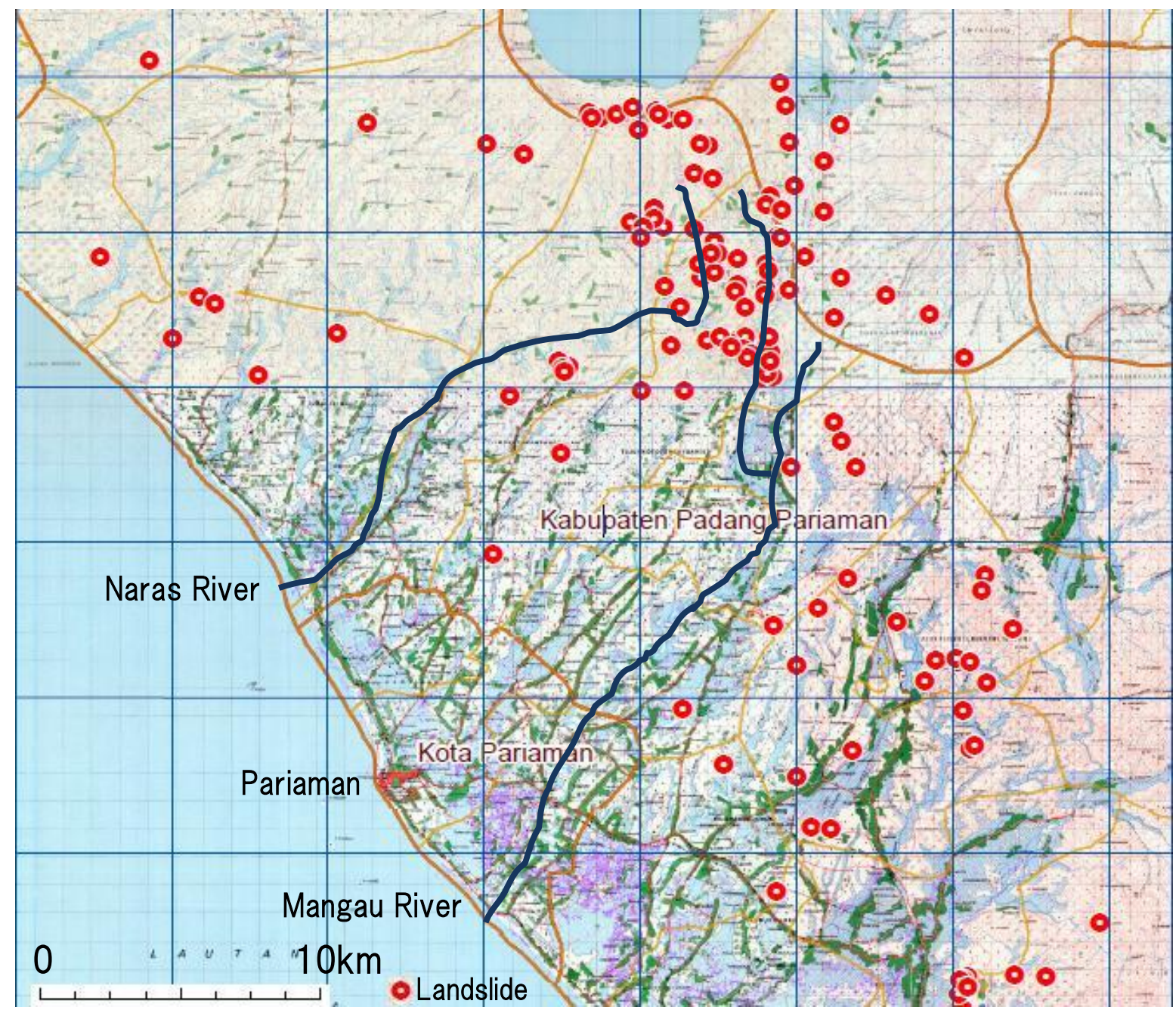

Fig.10 Landslide distribution in the Naras and Mangau river basins

\section{CONCLUSIONS}

Our field investigation and analyses of satellite images yielded the following conclusions regarding slope collapses during the Padang offshore earthquake.

1) Many slope collapses occurred in the upstream basins of the Naras and Mangau rivers.

2) Landslide occurrence was closely related to topography and geology, with landslides tending to occur on steep slopes of volcanic rock.

3) Some landslides became mudflows and flowed downstream. In these cases, large volumes of unstable sediment were deposited on slopes and in mountain streams. Water supplied by Lake Maninjau also contributed to mudflow occurrence.

\section{REFERENCES}

Frattini, P., Crosta, G., Fusi, N., Dal, Negro, P. (2004): Shallow landslides in pyroclastic soils: a distributed modelling approach for hazard assessment, Engineering Geology, 73, pp. 277-295.

Hürlimann, M., Ledesma, A., Martí, J. (2001): Characterisation of a volcanic residual soil and its implications for large landslide phenomena: application to Tenerife, Canary Islands, Engineering Geology, vol. 59, pp. 115-132.

Kastowo, G.W., Gafoer, L.S., Amin, T.C. (1996): Geological map of the Padang Quadrangle, Sumatera, Geological Research and Development Centre, Padang, 0715.

Zanchetta, G., Sulpizio, R., Pareschi, M.T., Leoni, F.M., Santacroce R (2004): Characteristics of May 5-6, 1998 volcaniclastic debris flows in the Sarno area (Campania, southern Italy): relationships to structural damage and hazard zonation. Journal of Volcanology and Geothermal Research, vol. 133, pp. 377-393.

Received: 18 June, 2010

Accepted: 23 November, 2012 